\title{
Mineralogical characteristics of phlogopite from Dupen kamen, Republic of Macedonia
}

\author{
Tena Sijakova-Ivanova ${ }^{1}$, Lidija Robeva Cukovska ${ }^{2}$ \\ ${ }^{1}$ Faculty of Natural and Technical Sciences,Štip, Republic of Macedonia \\ ${ }^{2}$ National Conservation Centre - Skopje, Republic of Macedonia
}

\begin{abstract}
In this paper are presented mineralogicalcharacteristicsof phlogopite from Dupen kamen, Republic of Macedonia. Several samples of phlogopite from Dupen kamenwere analysed by XRD, scanning electron microscope (SEM) and Infrared spectroscopy (IR).The use of these three methods showed that they are very useful methods for rapid mineral analysis contributing important analytical information. The results of the $X$ ray powder pattern. SEM analysis and Infrared spectroscopyenabled straightforward identification of the studied mineral sample as phlogopite.Phlogopite is located in a series ofmarblesthat are part ofthePelagonianmetamorphic complex. It occurs in yellow and gold yellow monoclinic-prismatic crystals. Transparent to translucent with vitreous lustre.Streak is white. Hardnessis 2-21/2 while density is $2.7-2.9$ $\mathrm{g} / \mathrm{cm}^{3}$. Cleavage is perfect on \{001\}.Concentration of $\mathrm{Mg}$ is 16.50-17.98\%, Al 6.16-7.31\%, Si 20.86-26.84\% while K from 8.59 to 9.93\%. Phlogpite in marble form Dupen kamen is considered that was formed probably by reaction between dolomite and earlier formed potassium feldspar or muscovite.
\end{abstract}

Keywords: phlogopite, (SEM)-scanning electron microscope, (X-ray)-powder diffraction(IR) infrared spectroscopy

\section{Introduction}

Dupen kamen is locatedabout 1 kmnorthwest ofthe villagePletvarnear Prilep in a series ofmarblesthat are part ofthePelagonianmetamorphiccomplex.Details on the locality Dupen kamen are obtained in the manufacture of base geological map of the R. Macedonia. Although they are regional researches they are a starting point for further research of any kind.

Mineralogical - petrographical studies of the rocks surrounding the village Pletvar, with special deals on marbles are performed by (Marik, L 1940; Dumurdzanov, N., 1976). Marbles of "Dupen kamen" are dolomite and calcite-dolomite. They have granoblastic structure, but in some places structure is a porfiroblastic. They have white or gray colour. White marble are composed of $6 \%$ calcite and $94 \%$ dolomite. Gray marble are composed of 97\% calcite and 3\% dolomite after (Rakicevic at all. 1965). Except phlogopite in studied white marblesalso appear following minerals: fluorite, calcite, pyrite, biotite and zoisite. White marbles from Dupen kamen are massive, compact and have high quality.

\section{Materials and methods}

The phlogopite was identified by Scanning electron microscopy (SEM), coupled with an energy dispersive X-ray spectrometer (EDS), X-ray diffraction (XRD) and Infrared spectroscopy (FTIR). The use of these three methods showed that they are very useful methods for rapid mineral analysis contributing important analytical information.

SEM is especially useful because it gives elemental, mineralogical and morphological data at the same time. Scaning electron microscopy model VEGA3 LMU and EDS-X-act: $10 \mathrm{~mm} 2$ connected with INCA 250 EDS software was used.

$\mathrm{X}$-ray diffraction (XRD) is known as the best method for the identification and quantification of minerals.Was used instrument XRD Shimadzu 6100. It was used copper radiation $\mathrm{CuK} \alpha=1.54178 \AA$, the voltage of the generator $40 \mathrm{kV}$, and the current was $30 \mathrm{~mA}, 2 \theta=2 \% \mathrm{~min}$.

Diffuse Reflectance Infrared Fourier Transform Spectroscopy (DRIFTS) was performed using IRPrestige 21 spectrophotometer equipped with a DRS-8000 diffuse reflectance accessory (Shimadzu, Japan). About $1 \mathrm{mg}$ of the powdered sample was diluted to about $5 \%$ by weight in dry $\mathrm{KBr}$. The mixture was then ground to a fine powder and placed into a sample holder ( $2 \mathrm{~mm}$ dia, $1 \mathrm{~mm}$ deep). The spectra was recorded in the spectral range $400-4000 \mathrm{~cm}^{-1}$ at a resolution of $4 \mathrm{~cm}^{-1}$ with 62 scans. Using this method the infrared spectra was obtained by measuring the diffuse reflected light that was emerged from the powder sample surface after first being absorbed inside the sample and reflected among the particles. For spectra manipulation was used IRSolution 1.5 software (Shimadzu Corporation). 


\section{Results and discussion}

The name phlogopite $\mathrm{KMg}_{3} \mathrm{AlSi}_{3} \mathrm{O}_{10}(\mathrm{~F}, \mathrm{OH})_{2}$ is from the Greek word meaning for fire, referring to an oft-seen reddish tintn. Appears in prismatic crystals with yellow and gold yellow colour. Cleavage is perfect $\{001\}$.Phlogopite is transparent to translucent. Luster is vitreous to pearly, (figure1). Streak is white. Hardness is $2 \frac{1}{2}$, while specific gravity is $2.7-2.9 \mathrm{~g} / \mathrm{cm}^{3}$. Phlogopite crystalize in monoclinic system $2 / \mathrm{m}, \mathrm{a}=5.31 \AA, b=$ $9.23 \AA, c=20.36 \AA, Z=4 ; \beta=99.3^{\circ} \mathrm{V}=984.75 \AA^{3}$.

In thin sections, under microscope phlogopite from Dupen kamen is observed as bronze brown to pale orange crystals with birefringenece of 0.040 . Weak pleochroism is observed. It is monoclinic, biaxial (-), although it behaves almost as monoaxial with very small angle between the optical axes $2 \mathrm{~V}=16^{\circ} ; \mathrm{a}=1.553$ $1.573, \mathrm{~b}=1.557-1.617, \mathrm{~g}=1.558-1.618$, bire=0.0280-0.0450, Dispersion weak to distinct, $\mathrm{r}$ < v. Pleochroisam: $(\mathrm{x})$ pale yellow to orange, (y) brownish yellow, reddish orange.

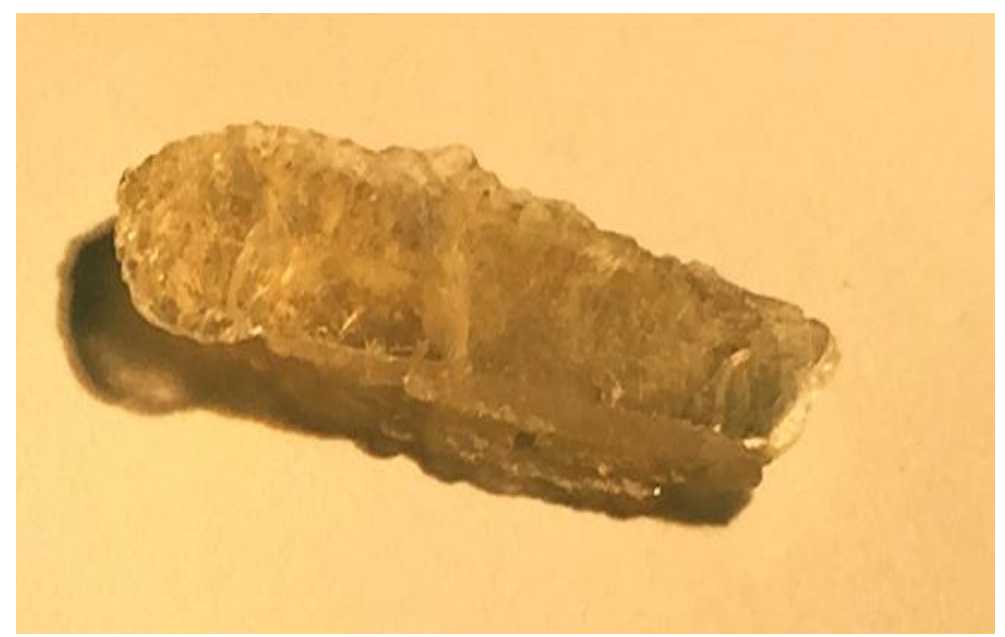

Figure 1: Phlogopite from Dupen kamen, R. Macedonia

The characterization of phlogopite by use of infrared spectroscopy was subject of study of many authors (Vedder, W. 1964; Farmer, V.C. 1974; Jenkins, D. M. 1989; Šontevska, V. et al. 2008). The FTIR analysis of phlogopite collected from Republic of Macedonia was described in detail by Šontevska et al. (2008). The aim of the infrared analysis included in this study is to demonstrate the DRIFT advantages in the characterization of the phlogopite collected from Dupen kamen locality in R. Macedonia. DRIFT is frequently used technique in the analysis of minerals because it requires simple sample preparation in comparison to other IR techniques (Madejova, J. 2003).

On figure 2 is presented the DR spectrum of the phlogopite from Dupen kamen together with its second derivative profile obtained according to the Savitzky-Golay method using IR Solution software program (Shimadzu Co. Japan). Table 2 summarizes the absorption maxima observed in the spectra of the studied mineral (figure 2) and spectral data from previous analysis of phlogopite mineral.

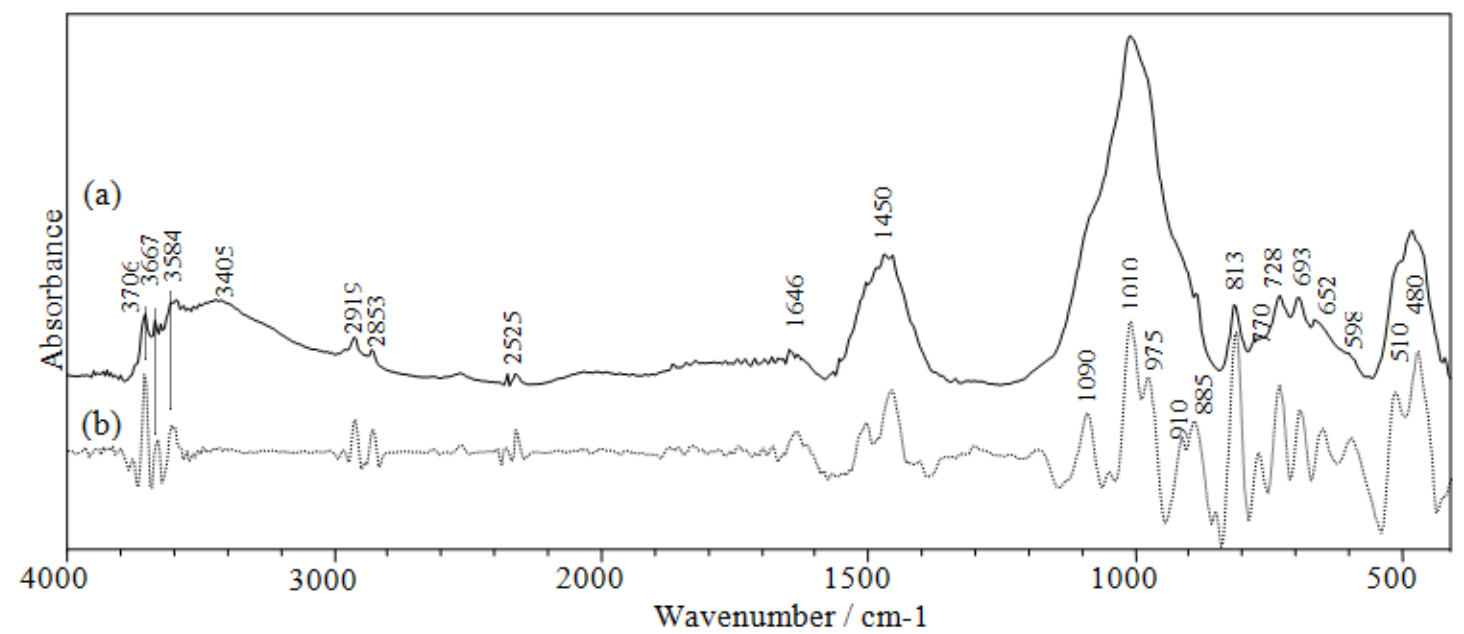

Figure2:(a) Spectrum of phlogopite recorded using DRIFT spectroscopy; (b) Second derivative profile of the original spectrum 
The absorption maxima in the spectrum obtained by DRIFT spectroscopy in comparison with the spectral findings from previous studies of phlogopite are given in table 1. In the highest spectral region (figure 2) three distinctive peaks arise at 3706,3667 and $3584 \mathrm{~cm}^{-1}$ corresponding to the stretching vibrations of the $\mathrm{OH}$ groups. Such appearance in the DR spectrum suggests that the reflectance has enhanced the peak intensities in comparison with the spectral features in this region obtained using $\mathrm{KBr}$ pellet method.

The resolution enhancement of the most intensive band $\left(1100-900 \mathrm{~cm}^{-1}\right)$ observed in the original spectrum (figure 2) enabled separation of the overlapping bands informative for Si-O-Si stretching vibrations: strong absorptions at $1010 \mathrm{~cm}^{-1}$ and weak absorption at $975 \mathrm{~cm}^{-1}$ observed as a shoulder in the original spectrum. These two bands together with the absorption noticeable at $693 \mathrm{~cm}^{-1}$ attributed to symmetric stretches (table 1) and those observed at the lower frequencies $\left(510\right.$ and $\left.480 \mathrm{~cm}^{-1}\right)$ associated to the Si-O-Si bending modes corroborate the spectral findings reported in the literature (Vedder, W. 1964; Farmer, V.C. 1974; Jenkins, D. M. 1989; Šontevska, V. et al. 2008).

According to the previous studies (Jenkins, D. M. 1989) the bands at 813 and $770 \mathrm{~cm}^{-1}$ are linked with the Al-O vibrations whereas the resolved band at 910 and $728 \mathrm{~cm}^{-1}$ could be related to $\mathrm{Si}-\mathrm{O}-\mathrm{Al}$ vibrations. The last band could also be assignable for carbonate matter present in the sample considering the set of bands appearing at: 2525, 1550-1450, 1090, 885 and $728 \mathrm{~cm}^{-1}$ indicative for $\mathrm{CO}_{3}$ vibrations (Jovanovski, G. et al. 2002).

The second derivative profile of the lower frequency region shows enhanced maximum of the corresponding very weak band at $598 \mathrm{~cm}^{-1}$ observed in the original spectrum. According to Farmer (Farmer, V.C. 1974; Sontevska et al. 2008) this band associated to the $\mathrm{OH}$ vibrations might serve as an indication for phlogopite low $\mathrm{OH}$ molar absorption coefficient.

Moreover, the spectral features in the $2920-2850 \mathrm{~cm}^{-1}$ region (figure 2) indicate presence of some organic matter in the studied mineral.The appearance of absorption band centered at around $3400 \mathrm{~cm}^{-1}$ and the weak band at around $1640 \mathrm{~cm}^{-1}$ can be explained by the $\mathrm{H}-\mathrm{O}-\mathrm{H}$ moleculesstretches of adsorbed water.

\begin{tabular}{|l|l|l|l|l|}
\hline $\begin{array}{l}\text { This study } \\
\text { natural phlogopite }\end{array}$ & \multicolumn{2}{|l|}{$\begin{array}{l}\text { Jenkins, D. M, (1989) } \\
\text { synthetic-powder }\end{array}$} & \multicolumn{2}{l|}{$\begin{array}{l}\text { Sontevska, V et al (2008) } \\
\text { natural phlogopite }\end{array}$} \\
\hline $3706 \mathrm{w}$ & & & $3705 \mathrm{vw}$ & $v(\mathrm{OH})$ \\
\hline $3667 \mathrm{w}$ & & & & \\
\hline $3584 \mathrm{w}$ & & & & \\
\hline $1010 \mathrm{vs}$ & $995 \mathrm{vs}$ & Si-O in plane & $1011 \mathrm{vs}$ & $v(\mathrm{Si}-\mathrm{O}-\mathrm{Si})$ \\
\hline $975 \mathrm{sh} *$ & $960 \mathrm{vs}$ & Si-O in plane & $977 \mathrm{sh}, \mathrm{s}$ & $v(\mathrm{Si}-\mathrm{O}-\mathrm{Si})$ \\
\hline $910^{*}$ & $915 \mathrm{~s} *$ & Si-O-Al in plane & & \\
\hline $813 \mathrm{~m}$ & $822 \mathrm{~ms}$ & Al-O perp & $813 \mathrm{w}$ & $v(\mathrm{Al}-\mathrm{O}-\mathrm{Al})$ \\
\hline $770 \mathrm{vw}$ & $760 \mathrm{vw}$ & Al-O in plane & & \\
\hline $728 \mathrm{w}$ & $725 \mathrm{w}$ & Al-O-Si in plane & $727 \mathrm{sh}$ & $v(\mathrm{Al}-\mathrm{O}-\mathrm{Si})$ \\
\hline $693 \mathrm{~m}$ & $690 \mathrm{~ms}$ & Si-O-Mg & $692 \mathrm{~m}$ & $v \mathrm{~s}(\mathrm{Si}-\mathrm{O}-\mathrm{Si})$ \\
\hline $652 \mathrm{vw}$ & $655 \mathrm{w}$ & Al-O in plane & & $v(\mathrm{Al}-\mathrm{O})$ \\
\hline $598 \mathrm{vw}$ & $592 \mathrm{~ms}$ & OH libration & & $\mathrm{L}(\mathrm{OH})$ \\
\hline $510 \mathrm{sh}$ & $520 \mathrm{vs} *$ & Si-O perp & $511 \mathrm{sh}$ & $\delta(\mathrm{Si}-\mathrm{O}-\mathrm{Si})$ \\
\hline $480 \mathrm{~s}$ & $495 \mathrm{vs}$ & Mg-O & $470 \mathrm{vs}$ & $\delta(\mathrm{Si}-\mathrm{O}-\mathrm{Si})$ \\
\hline & $460 \mathrm{vs}$ & Si-O in plane & & \\
\hline
\end{tabular}

Table 1:The absorption maxima in the spectrum obtained by DRIFT spectroscopy in comparison with the spectral findings from previous studies of phlogopite.

Abbreviation: w-weak, v-very, s-strong, m-moderately, sh-shoulder; * = resolved band. In Jenkins, D. M. 1989: orientation of vibration - parallel (in plane) or perpendicular (perp) to the cleavage plane.

Morphology of phlogopite from Dupen kamen observed with SEM shows thin platy, layered crystals (figure3). Ideal chemical formula of phlogopite is $\mathrm{KMg}_{3}\left(\mathrm{Si}_{3} \mathrm{Al}\right) \mathrm{O}_{10}(\mathrm{~F}, \mathrm{OH})_{2}$. The $\mathrm{Mg}$ content in the studied phlogopiteis is $16.50-17.98 \%, \mathrm{Al}$ is between $6.16-7.31 \%, \mathrm{Si}$ is from 20.86 to $26.84 \%$ while $\mathrm{K}$ from 8.59 to $9.93 \%$.

According to its chemical composition and considering the Nomenclature of the micas (Rieder et al. 1998) the mineral is determined as phlogopite. On table 2 is given the chemistry of phlogopite from Dupen kamen. 


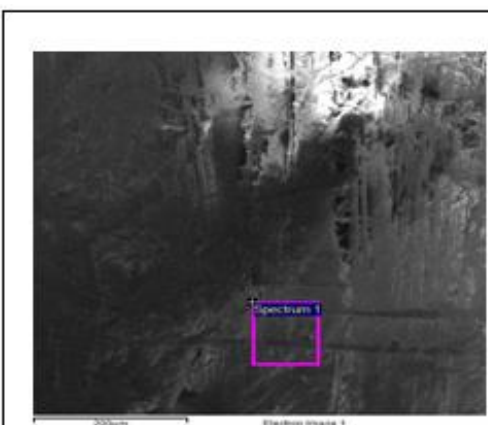

a)spectrum 1

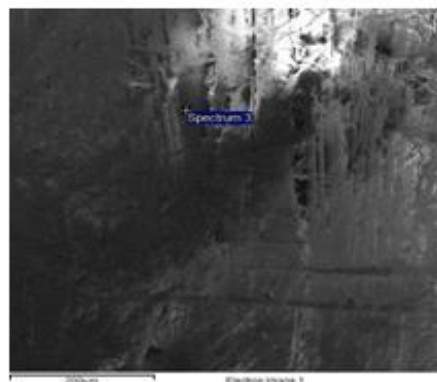

b)spectrum 2

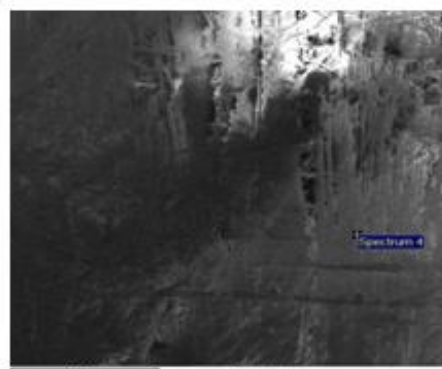

c) spectrum 3

Figure 3:SEM images of phlogopite:a)spectrum 1; b)spectrum 2; c) spectrum 3

\begin{tabular}{|l|l|l|l|l|l|l|}
\hline & \multicolumn{2}{|l|}{ Spectrum 1 } & \multicolumn{2}{l|}{ Spectrum 2 } & \multicolumn{2}{l|}{ Spectrum 3 } \\
\hline Element & Weight\% & Atomic\% & Weight\% & Atomic\% & Weight\% & Atomic\% \\
\hline $\mathrm{O}$ & 44.43 & 58.30 & 39.09 & 52.88 & 46.74 & 60.44 \\
\hline $\mathrm{Mg}$ & 17.64 & 15.23 & 17.98 & 16.01 & 16.50 & 14.04 \\
\hline $\mathrm{Al}$ & 6.29 & 4.89 & 6.16 & 4.94 & 7.31 & 5.61 \\
\hline $\mathrm{Si}$ & 21.79 & 16.29 & 26.84 & 20.68 & 20.86 & 15.37 \\
\hline $\mathrm{K}$ & 9.85 & 5.29 & 9.93 & 5.49 & 8.59 & 4.55 \\
\hline Totals & 100.00 & 100.00 & 100.00 & 100.00 & 100.00 & 100.00 \\
\hline
\end{tabular}

Table 2: Chemistry of phlogopite from Dupen kamen (spectrum 1, 2 and 3)

The first researcher to describe X-ray diffraction examination of mica was Mauguit $(1927,1928)$, who determined the symmetry, unit cell dimensions, and cell content of several natural specimens. Shortly thereafter the basic crystal structure of mica was proposed almost simultaneously by Pauling (1930) and Jackson and West (1930, 1933). Pabst (1955) presented theoretical atomic coordinates for an "ideal" C2f m, one-layer, trioctahedral mica and this model has been subsequently described and illustrated by several authors (e.g., Bragg et al 1965, p. 254 et seq). Phlogopite structure is basic for 1M trioctahedral micas. Rayner (1974) refined this structure using single-crystal neutron diffraction reflection data, which permitted precise determination of $\mathrm{H}$ atom position.

The most intense registered maxima in the studied powder diagram (figure 4) are: 3.338(100), $2.614(30), 2.009(30), 3.390(20), 2.513(16), 2.429(16)$. They were compared with the corresponding maxima in the diagram of phlogopite sampleJCPDScards 01073 7742. The comparison has shown that the X-ray powder pattern of the natural phlogopite taken from the JCPDS card are practically identical with the obtained results in this stady.

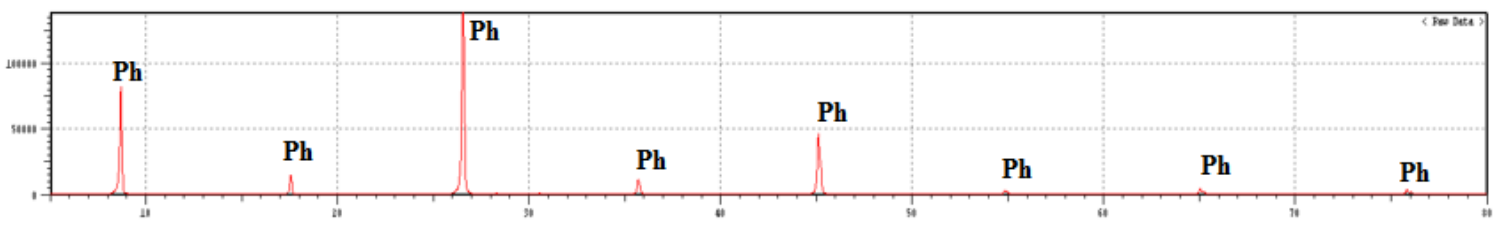

Figure 4:X-ray diagram of phlogopite

\section{Conclusion}

After summarizing the data collected in this research, we canconfirm that the studied mineral sample is phlogopite. The straightforward identification of the studied mineral sample was enable by X-ray powder pattern, SEM analysis and IR spectroscopy.

Phlogopite is located in a series ofmarblesthat are part ofthePelagonianmetamorphic complex. It occurs in yellow and gold yellow monoclinic-prismatic crystals. Streak is white. Phlogopite is transparent to translucent. Lustre is vitreous. Hardnes is $2-21 / 2$ and the density $2.7-2.9 \mathrm{~g} / \mathrm{cm}^{3}$. Cleavage is perfect on $\{001\}$.

The $\mathrm{Mg}$ content in the studied phlogopite varies from 16.50 to17.98\%, Al is within between6.16 and $7.31 \%$, Si vary from $20.86-26.84 \%$ while concentrations of $\mathrm{K}$ in range of 8.59 to $9.93 \%$. Resultsobtained byXrayinvestigationsare in goodagreementwithJCPDScards 010737742.

The spectral features of phlogopite achieved by use of DRIFT spectroscopy are in agreement with the previous studies of this mineral by use of $\mathrm{KBr}$ pellet method.

Phlogpite in marble form Dupen kamen is considered that was formed probably by reaction between dolomite and earlier formed potassium feldspar or muscovite. 
$3 \mathrm{CaMg}\left(\mathrm{CO}_{3}\right)_{2}+\mathrm{KAlSi}_{3} \mathrm{O}_{8}+\mathrm{H}_{2} \mathrm{O} \rightarrow(\mathrm{OH})_{2} \mathrm{KMg}_{3} \mathrm{Al} \mathrm{Si} \mathrm{O}_{10}+3 \mathrm{CaCO}_{3}+3 \mathrm{CO}_{2}$

$3 \mathrm{CaMg}\left(\mathrm{CO}_{3}\right)_{2}+(\mathrm{OH}) \mathrm{KAlSi}_{3} \mathrm{O}_{8} \rightarrow(\mathrm{OH})_{2} \mathrm{KMg}_{3} \mathrm{Al} \mathrm{Si}_{3} \mathrm{O}_{10}+3 \mathrm{CaCO}_{3}+3 \mathrm{CO}_{2}+\mathrm{Al}_{2} \mathrm{O}_{3}$ daily life.

Phlogopite is economically importantmineral because is a major constituent in various products of our

\section{References}

[1]. Bragg, W. L., G. F. Claringbull, and W. H. Tevron (1965) The Crystal Stuctures ol Minerals. Cornell University Press, Ithaca, N.Y., 409'pp.

[2]. Dumurdzanov, N., Hristov, S., 1976, Basic geological map 1: 100000 for the page Prilep, Geological Institute, Skopje

[3]. Farmer, V.C. 1974: The layer silicates. In: The Infrared Spectra of Minerals, Farmer V.C. (Ed) Mineralogical Society, London. 331-363.

[4]. Hazen, R. M., Burnham, C. W. 1973: The crystal structures of one-layer phlogopite and annite, American Mineralogists, 58, 889900.

[5]. Jacson, W. W., end J. West (1930) The crystal structure of muscovite. Z. Kristallogr. 76, 211-227

[6]. Jenkins, D. M. 1989: Empirical study of the infrared lattice vibrations $\left(1100-350 \mathrm{~cm}^{-1}\right)$ of phlogopite, Physics and Chemistry of Minerals, 1989, 16, 408-414.

[7]. Jenkins, D. M. 1989: Phys. Chem. Min., 16, 408-414.

[8]. Jovanovski, G., Stefov, V., Šoptrajanov, B., Boev, B, 2002: Minerals from Macedonia. IV. Discrimination between some carbonate minerals by FTIR spectroscopy, N. Jh. Miner. Abh. 177, 241.

[9]. Madejova, J. 2003: FTIR techniques in clay minerals studies, Vibrational Spectroscopy, 31, 1, 1-10.

[10]. Marik L., 1940 Petrological and geological structure surroundings of Prilep. Geol. Inst. Jug. book VII Beograd.

[11]. Mauguin, M. Ch. (1927) Etude du mica muscovite au moyens des rayons X. C.R. Acad. Sci. Paris, 185' 288- 291

[12]. Milan Rieder and all. 1998: Nomenclature of the micas, The Canadian Mineralogist Vol. 36, pp. X-xx

[13]. Müller C. M., et al. 2014: Infrared Attenuated Total Reflectance Spectroscopy: An Innovative Strategy for Analyzing Mineral Components in Energy Relevant Systems, Scientific Reports 4.

[14]. Pabst, A. (1955) Redescription of the single layer structure of the micas. Amer. Mineral.40,967-974.

[15]. Pauling, L. (1930) The structure of micas and related minerals. Proc. Nat. Acad. Sci. 16, 123-129

[16]. Rayner JH (1974) The crystal structure of phlogopite by neutron diffraction. Mineralogical Magazine, 39, 850-856

[17]. Rakicevic, T., Stojanov, R., Arsovski, M., 1965: Explanation for the page Prilep, BGM SFRY 1 : 100 000, Geological Institute, Skopje.

[18]. Šontevska, V., Jovanovski, G., Makreski, P., Raškovska, A., Šoptrajanov, B. 2008: Minerals From Macedonia. XXI.Vibrational Spectroscopy as Identificational Tool for Some Phyllosilicate Minerals, Acta Chim. Slov., 55, 757-766.

[19]. Stubičan, V., Roy, R. 1961: Am. Mineral., 46, 32-51.

[20]. Vedder, W., 1964: Correlations between infrared spectrum and chemical compositions of mica, Amer. Mineral., 49, 736-768. 